\title{
Implementasi ISM Code dalam Meningkatkan Keselamatan Pelayaran Kapal di Pelabuhan Tanjung Intan Cilacap
}

\author{
Indriyani ${ }^{1}$, Robertus Igang $\mathrm{P}^{2}$, Tiara Pandansari ${ }^{3}$ \\ ${ }_{1,2}^{1}$ Akademi Maritim Nusantara, Cilacap \\ ${ }^{3}$ Universitas Muhammadiyah Purwokerto, Purwokerto

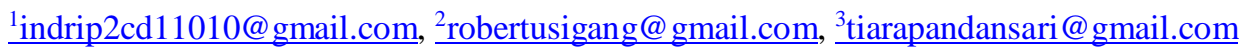

Diterima 14 Januari 2021, direvisi 08 Februari 2021, diterbitkan 08 Maret 2021

\begin{abstract}
Abstrak
Penelitian ini memiliki tujuan mengetahui pengaruh implentasi ISM Code dalam meningkatkan keselamatan pelayaran. Penelitian ini merupakan penelitian kuantitatif dengan mengambil sampel sebanyak 75 orang yang merupakan crew kapal dari Departemen Dek dan Departemen Mesin yang melakukan kegiatan bongkar muat di Pelabuhan Tanjung Intan Cilacap. Analisis data menggunakan regresi linier sederhana. Penelitian ini menunjukkan bahwa penerapan ISM Code berpengaruh terhadap keselamatan pelayaran.
\end{abstract}

Kata kunci : : ISM Code, Keselamatan Pelayaran

\section{Abstract}

This study aims to determine the effect of ISM Code implementation in improving shipping safety. This research is a quantitative study by taking a sample of 75 ship crews in the Deck Department and the Engine Department who carry out loading and unloading activities at the Port of Tanjung Intan Cilacap. Data analysis using simple linear regression. This study shows that the application of the ISM Code has an effect on shipping safety.

Keywords: ISM Code, Shipping Safety

\section{Pendahuluan}

Berdasarkan Undang-Undang Nomor 17 Tahun 2008 Pasal 1 butir (1), pelayaran merupakan suatu sistem yang menyatukan angkutan di perairan, pelabuhan, keamanan, keselamatan, serta melindungi lingkungan kemaritiman [1]. Berkaitan dengan hal tersebut maka dibutuhkan berbagai alat penunjang, sistem pengawasan, serta perawatan yang rutin dalam upaya meningkatkan keselamatan pelayaran. UU tersebut juga menjelaskan tugas Kesyahbandaran dan Otoritas Pelabuhan (KSOP) yaitu mengawasi, menegakkan hukum, berkoordinasi, mengatur, mengendalikan, dan mengawasi kegiatan pelayaran.

Salah satu wilayah KSOP yang berada di Pantai Selatan Pulau Jawa adalah KSOP Kelas II Pelabuhan Tanjung Intan Cilacap yang secara geografis terletak pada $07^{\circ} 43^{\prime} 55.45^{\prime \prime} \mathrm{S}$ dan
108 59'32.91" E dan dikelilingi hinterland komoditi ekspor dan terlindungi Pulau Nusakambangan.

KSOP Kelas II Cilacap melaksanakan tugastugas umum Kesyahbandaran dan Otoritas Pelabuhan di lingkungan Pelabuhan Tanjung Intan Cilacap dengan memperhatikan berbagai aspek yang menunjang keselamatan pelayaran salah satunya adalah penerapan INTERNATIONAL SAFETY MANAGEMENT (ISM) CODE. Menurut Mudiyanto penggunaan ISM Code adalah memberi kepastian pengamanan di laut, pencegahan kecelakaan yang terjadi pada manusia dan penghindaran lingkungan laut yang rusak [2].

Patayang, M., \& Lia, R melakukan penelitian elemen 10 ISM CODE untuk menunjang keselamatan pelayaran berupa adanya kelengkapan alat keselamatan dan kondisi alat keselamatan yang berfungsi dengan baik, 
dokumen-dokumen berupa fire control plan, muster list, emergensi prosedur, nautikal publication, dan jadwal perawatan perlengkapan kapal[3] sedangkan mudiyanto (2018) menyatakan bahwa variabel Document of Compliancel DOC dan Safety Management Certificate/SMC berhubungan kuat dengan keselamatan pelayaran.

Penelitian ini menggunakan indikator perlindungan lingkungan air, prosedur perawatan kapal dan dokumen keselamatan yang merupakan indikator penting dalam menunjang keselamatan pelayaran.

\section{Materi dan Metode}

Pada tahun 1994 SOLAS (Safety of Life At Sea) mengadopsi salah satu produk IMO (International Maritime Organization) yaitu ISM (International Safety Management) Code [4]. ISM Code menetapkan suatu peraturan yang berkaitan dengan manajemen pengoperasian kapal yang aman melalui penerapan Safety Manajemen System (SMS) dengan mengikuti konsep-konsep dari ISO (International Organization for Standardization). Kapal-kapal yang akan melakukan kegiatan pelayaran diuji dan diberikan sertifikat berupa DOC (Document Of Compliance) pada perusahaan pelayaran dan SMC (Safe Management Certificate) pada kapal yang sudah melalui tahap uji dan tahap kelayakan.

Penelitian ini menggunakan metode penelitian kuantitatif. Pengambilan populasi dengan metode populasi terhingga. Populasi tersebut diambil berdasarkan data jumlah kapal yang melakukan aktivitas di Pelabuhan Tanjung Intan Cilacap dalam kurun waktu 1 (satu) minggu. Dimana jumlah crew dalam 1 kapal \pm 20 orang. Ada sebanyak 15 cargo vessel dalam 1 (satu) minggu yang melakukan aktivitas di Pelabuhan Tanjung Intan Cilacap dikali 20 awak kapal sama dengan 300 orang. Responden yang dipilih adalah crew kapal pada Departemen Dek dan Departemen Mesin.

Jumlah sampel diperoleh jumlah kapal yang masuk pelabuhan dalam minggu ke-2 (dua) bulan Juni 2020 sebanyak 15 kapal dengan mengambil sampel sebanyak jumlah crew kapal sebanyak 300 orang. Karena populasinya terhitung, maka ditentukan jumlah sampel :

$$
\begin{aligned}
n & =\frac{N}{1+\mathrm{Ne}^{2}} \\
& =\frac{300}{1+\left(300.10 \%^{2}\right)}
\end{aligned}
$$

$$
\begin{aligned}
& =\frac{300}{1=(300.0,01)} \\
& =\frac{300}{1+3} \\
& =\frac{300}{4} \\
& =75 \text { orang }
\end{aligned}
$$

Dimana :

$\mathrm{n}=$ Jumlah Sampel

$\mathrm{N}=$ Jumlah Populasi

$\mathrm{E}=$ Jumlah kelonggaran kesalahan yang dilakukan (10\%).

Jadi diperoleh hasil hitungan tersebut diatas maka dapat disimpulkan bahwa penelitian ini menggunakan sampel berjumlah 75 responden.

Pada penelitian ini, penggunaan metode angket untuk data kualitatif dan dirubah menjadi data kuantitati dengan menggunakan rumus slovin. Untuk mendapatkan data kuantitatif, maka digunakan Skala Likert dimana penggunaan Skala Likert untuk pengukuran sikap, pendapat dan persepsi satu orang maupun kelompok orang. Dengan skala likert, pengukuran variabel akan dibuat penjabaran menjadi indikator variabel [5].

Penentuan nilai score pada Skala Likert sebagai berikut:

1. Score 5 artinya Sangat Setuju

2. Score 4 artinya Setuju

3. Score 3 artinya Cukup Setuju

4. Score 2 artinya Tidak Setuju

5. Score 1 artinya Sangat Tidak Setuju

\section{Hasil dan Pembahasan}

Indikator ISM Code dalam penelitian ini yaitu:

1. Perlindungan Lingkungan Perairan

2. Prosedur Perawatan Kapal

3. Dokumen Keselamatan

\section{Uji Validitas}

Uji validitas pada penelitian ini penulis menggunakan analisis korelasi bivariate. Diketahui bahwa besaran $r$ table adalah 0.227. Syarat uji validitas yaitu :

a. Jika $r_{\text {hitung }}>r_{\text {tabel, }}$ maka item pernyataan valid.

b. Jika $\mathrm{r}_{\text {hitung }}<\mathrm{r}_{\text {tabel, }}$ maka item pernyataan tidak valid. 
Tabel 1. Pengujian Validitas Penerapan ISM Code

\begin{tabular}{cccc}
\hline $\begin{array}{c}\text { Indikator } \\
\text { Penelitian }\end{array}$ & $\mathrm{r}_{\text {hitung }}$ & $\mathrm{r}_{\text {tabel }}$ & Kriteria \\
\hline $\mathrm{X}_{1}$ & 0,860 & 0.227 & Valid \\
$\mathrm{X}_{2}$ & 0,788 & 0.227 & Valid \\
$\mathrm{X}_{3}$ & 0,828 & 0.227 & Valid \\
\hline
\end{tabular}

Sumber : Output SPSS Ver 22,0 2020

Berdasarkan tabel diatas dapat disimpulkan bahwa indikator penelitian yang digunakan pada variabel Penerapan ISM Code menunjukkan hasil yang signifikan, untuk kesimpulannya bahwa semua indikator penelitian tersebut adalah valid, yaitu dimana besaran nilai $r$ hitung $>r$ tabel.

\section{Uji Reliabilitas}

Tabel 2. Pengujian Reliabilitas

\begin{tabular}{lccc}
\hline Variabel & $\begin{array}{c}\text { Cronbac } \\
\text { h Alpha }\end{array}$ & $\begin{array}{c}\text { Alpha } \\
\text { Standa } \\
\mathrm{r}\end{array}$ & $\begin{array}{c}\text { Kesimpul } \\
\text { an }\end{array}$ \\
\hline $\begin{array}{l}\text { Penerapan } \\
\begin{array}{l}\text { ISM Code } \\
\text { (X) }\end{array}\end{array}$ & 0,766 & 0,70 & Reliabel \\
\hline \multicolumn{3}{c}{ Sumber : Output SPSS Ver 22,0 2020 }
\end{tabular}

Berdasarkan 75 responden, melakukan uji reliabilitas, dimana jika hasil dari variabel melebihi 0,70 artinya reliabwl.

Hasil yang didapat dari pengujian reliabilitas variable ISM Code menunjukkan hasil 0.776 serta lebih tinggi dari alpha standar 0.70, maka hasilnya adalah reliabel.

\section{Persamaan Regresi Linier Sederhana}

Untuk mengetahui Peranan ISM Code Sebagai Penunjang Keselamatan Pelayaran, digunakan analisis persamaan regresi linier sederhana.

$$
\mathbf{Y}=\alpha+\beta_{1} X_{1}+\mu
$$

a. Konstanta (a) $=1,623$ Nilai konstanta $(\mathrm{a})=$ 1,623 artinya jika variabel peranan sistem ISM Code tidak ada, maka nilai variabel keselamatan pelayaran $(\mathrm{Y})=1,623$.

b. Koefisien regresi b1 $=0,242$ Artinya apabila ISM Code naik satu satuan, maka keselamatan pelayaran (Y) akan naik senilai 0,242 .

c. Selain itu terdapat faktor lain yang mempengaruhi sebesar $\boldsymbol{\mu}(\mathbf{m i u})$, seperti cuaca, iklim kerja, kemampuan crew kapal, dan faktor lainnya.

\section{Uji T}

Untuk mengetahui hasil dari pengujian uji t, maka dicari besaran nilai $t$ table dengan cara :

a. Apabila $t_{\text {hitung }}>t$ tabel maka Ha diterima

b. Apabila $t_{\text {hitung }}<t$ tabel maka Ha ditolak

c. responden $(n)=75$

d. variabel indpenden $(\mathrm{k})=1$

e. Tingkat signifikan $(\alpha)=0,050$ (uji 2 sisi)

Tabel 3. Hasil Uji T

\begin{tabular}{ccc}
\hline Model & $\mathrm{T}$ & Sig. \\
\hline Contanst & 1,759 & 0,083 \\
$\mathrm{X}_{1}$ & 2,073 & 0,042 \\
\hline
\end{tabular}

Sumber : Output SPSS Ver 22,0 2020

Uji hipotesis antara variabel Penerapan ISM Code terhadap Variabel Y (Keselamatan Pelayaran) mendapatkan hasil yang menunjukan nilai thitung dari variable ISM Code sebesar 2.073, jadi nilai thitung $(2.073)>$ tabel (1.99394).

Jadi variabel Penerapan ISM Code memiliki pengaruh positif dan signifikan terhadap Peningkatan Keselamatan Pelayaran pada Pelabuhan Tanjung Intan Cilacap.

\section{Kesimpulan}

Penelitian ini menyatakan bahwa variabel Penerapan ISM Code berpengaruh positif dan signifikan terhadap peningkatan keselamatan pelayaran. Positif dibuktikan dengan koefisien penerapan ISM Code sebesar 0,242 yang bertanda positif dan signifikan dan dibuktikan dengan diperoleh hasil perhitungan uji t dengan besaran thitung (2.073) > tabel (1.996) dengan tingkat signifikan 0,042 terhadap peningkatan Keselamatan Pelayaran.

Kapal yang memenuhi persyaratan sesuai indikator ISM Code dalam penelitian ini yaitu perlindungan lingkungan perairan, prosedur perawatan kapal, dokumen keselamatan terbukti berhasil meningkatkan Keselamatan Pelayaran di Pelabuhan Tanjung Intan Cilacap.

\section{Ucapan terima kasih}

Penulis mengucapkan terima kasih pada Akademi Maritim Nusantara Cilacap, Pelabuhan Tanjung Intan serta para kru kapal yang mendukung penelitian ini.

\section{Daftar Pustaka}

[1] Undang-Undang 17 Republik Indonesia, 
"UU 17 tahun 2008 tentang Pelayaran," Vis. Comput., 24 (3), 155-172, (2008).

[2] Mudiyanto, "Safety, International Code, Management Certificate, Safety Management," J. Apl. pelayaran dan kepelabuhanan, vol. 9, (2018).

[3] M. Patayang and R. Lia, "Penerapan Elemen ISM Code Untuk Menunjang Keselamatan Pelayaran Pada Km Pantokrator," Sebatik, 23 (2), 482-488, (2019).

[4] N. Nurhasanah, A. Joni, and N. Shabrina, "Persepsi Crew dan Manajemen dalam Penerapan ISM Code Bagi Keselamatan Pelayaran dan Perlindungan Lingkungan Laut," Proceeding SENDI_U, 978-979, (2015).

[5] Citra Kunia putri dan trisna insan Noor, "Sistem Pengendalian Internal, Pemanfaatan Teknologi Informasi, Kapasitas Sumber Daya Manusia terhadap Kualitas Laporan Keuangan (Studi BPKAD Pemerintah Kota Bandung)," Anal. pendapatan dan tingkat Kesejaht. rumah tangga petani, 53 (9), 1689-1699, (2013). 